\title{
Screening for Lung Cancer with Low-Dose CT Scans
}

\author{
James R. Jett
}

Division of Oncology, Clinical and Translational Research Section, National Jewish Health, Colorado

\begin{abstract}
Lung cancer is the leading cause of cancer deaths in males and the second leading cancer cause of death in females. The 5 -year survival of all lung cancer patients in the United States is $16 \%$. Only $15 \%$ of new lung cancers are stage I at the time of diagnosis, and over $50 \%$ of patients have stage IV lung cancer at diagnosis. Most lung cancers are not diagnosed until the patient presents with signs or symptoms of disease, and these are usually due to advanced-stage disease. If we are going to increase the cure rate for lung cancer, then more cases must be detected while the patient is asymptomatic and before the cancer has spread. Screening of high-risk individuals with low-dose computed tomography (LDCT) may help in diagnosing the lung cancer at earlier stages. Screening with LDCT in high-risk individuals is becoming the standard of care in the United States and, along with smoking cessations, offers the best opportunity for decreasing a substantial number of lung cancer deaths. In this article, recent manuscripts about lung cancer screening with LDCT have been reviewed.
\end{abstract}

Keywords: Lung cancer, screening, low-dose CT scan

\section{Özet}

Kansere bağlı ölüm nedenleri arasında akciğer kanseri erkeklerde birinci sırada, kadınlarda da ikinci sırada yer almaktadır. Amerika Birleşik Devletleri'nde akciğer kanseri hastalarının 5 ylllk hayatta kalma oranı \%16'dır. Akciğer kanseri hastalarının sadece \%15'i tanı aşamasında 1. evrededir. Hastaların \%50'den daha fazlasının tanı anında IV. evre oldukları görülmektedir. Çoğu akciğer kanseri hastasına, hastalık ileri düzeye ulaștığında kendini gösteren belirti ve semptomlar ortaya çkana kadar tanı konulamamaktadır. Akciğer kanserinin tedavi oranının artırlması için, hasta asemptomatik iken ve kanser yayllmadan önce daha fazla sayıda vaka tespit edilmelidir. Yüksek risk altındaki bireylerde düsük-doz bilgisayarlı tomografi (DDBT) taraması, akciğer kanserinin erken evrelerde teşhis edilmesine yardımcı olabilir. ABD'de yüksek risk altındaki bireylerde DDBT taramasi, standart haline gelmektedir ve akciğer kanserinden kaynaklanan ölümlerin sayısında, sigaranın bırakulması ile birlikte önemli ölçüde bir azalma sağlamaktadır. Bu makalede, DDBT ile akciğer kanseri taraması hakkında son zamanlarda yapılmış olan çalışmalar incelenmiştir.

Anahtar Kelimeler: Akciğer kanseri, tarama, düşük-doz BT taraması
Received Date / Alındığı Tarih: 03.05.2014 Accepted Date / Kabul Tarihi: 06.05.2014

Address for correspondence / Yazışma Adresi James R. Jett, Department of Oncology, National Jewish Health, Colorado, USA E-posta / E-mail: JettJ@njhealth.org

(C) Copyright 2014 Turkish Respiratory Society (TRS) Eurasian J Pulmonol 2014

DOI: 10.5152/ejp.2014.98698

-Available online at www.eurasianjpulmonol.com

\section{INTRODUCTION}

GLOBOCAN 2012 reported that lung cancer is the leading cause of cancer deaths in males and the second leading cancer cause of death in females. Lung cancer accounts for $19.4 \%$ (1.6 million) of all cancer deaths in 2012 (1). GLOBOCAN reports data by countries, including Turkey. In Turkey, lung cancer causes $25 \%$ of all new cancers in men and accounts for $32 \%$ of all cancer deaths. In Turkish women, lung cancer accounts for $7 \%$ of all new cancers and $11 \%$ of cancer deaths (1). These estimates come from high-quality regional data, but coverage is lower than $10 \%$ of the country.

In 2014, it is estimated that there will be 224,000 new cases of lung cancer in the United States and 159,000 deaths from lung cancer. Lung cancer accounts for $28 \%$ of all cancer deaths in males and $26 \%$ of cancer deaths in females (2). The 5-year survival of all lung cancer patients in the United States is $16 \%$. Only $15 \%$ of new lung cancers are stage I at the time of diagnosis, and over $50 \%$ of patients have stage IV (incurable) lung cancer at diagnosis. Most lung cancers are not diagnosed until the patient presents with signs or symptoms of disease, and these are usually due to advanced-stage disease. If we are going to increase the cure rate for lung cancer, then more cases must be detected while the patient is asymptomatic and before the cancer has spread.

\section{The National Lung Screening Trial (NLST)}

The NLST was a screening trial for lung cancer in the United States that randomized 53,454 high-risk individuals to low-dose (radiation) CT (LDCT) or a single-view posterior-anterior chest radiograph for three annual screenings, and then, participants were followed for a median of 6.5 years (3).

Low-dose CT detected more than twice as many lung cancers as the chest radiograph (649 vs. 279) in the 3 years of active screening, and $63 \%$ of the lung cancers detected by $\operatorname{LDCT}$ were stage IA/B $(4,5)$. 
(Figure 1) Screening with LDCT resulted in 20\% lung cancer mortality reduction as compared to chest radiography ( 247 vs. 309 deaths per 100,000 person-years). Additionally, the rate of death from any cause was reduced in the LDCT group by $6.7 \%$. This was the largest randomized prospective lung cancer CT screening trial ever conducted and, to date, is the only lung cancer screening trial to document a mortality reduction with LDCT screening.

\section{Limitations of NLST}

Over-diagnosis is generally defined as the detection of a cancer that would never have been detected without screening and never would have led to symptoms or death. Perhaps the best example of this is 1-2 - cm adenocarcinomas in situ with an estimated volume doubling time (VDT) of 600 days or longer. In an Italian CT screening trial, slow-growing cancers had a VDT of 400-599 days, and indolent cancers had a VDT of 600 days or longer. Slow-growing or indolent cancers accounted for $25 \%$ of the incident lung cancers (Figure $2 a, b)(6)$.

In the NLST, there were 120 more lung cancers diagnosed on the LDCT versus chest radiograph arm. The estimates of over-diagnosis from a clinical perspective were $18.5 \%$ (120/649) or $11 \%$ (120/1089) from a public health perspective (7). The comparative modeling study for the US Preventive Services Task Force reported estimates of over-diagnosis with LDCT screening of $8.7 \%-13.1 \%$ (8).

Thoracic operations for benign disease are significant negative to screening for lung cancer. In the first year of NLST, 90 of 297 (30\%) of all surgical procedures in the LDCT arm were for benign disease (4). This decreased to $18.9 \%$ in the second year and $15.9 \%$ in the third year of screening in the LDCT arm. The data suggest that there was a learning curve for physicians and with time, and fewer indeterminate nodules were resected (5).

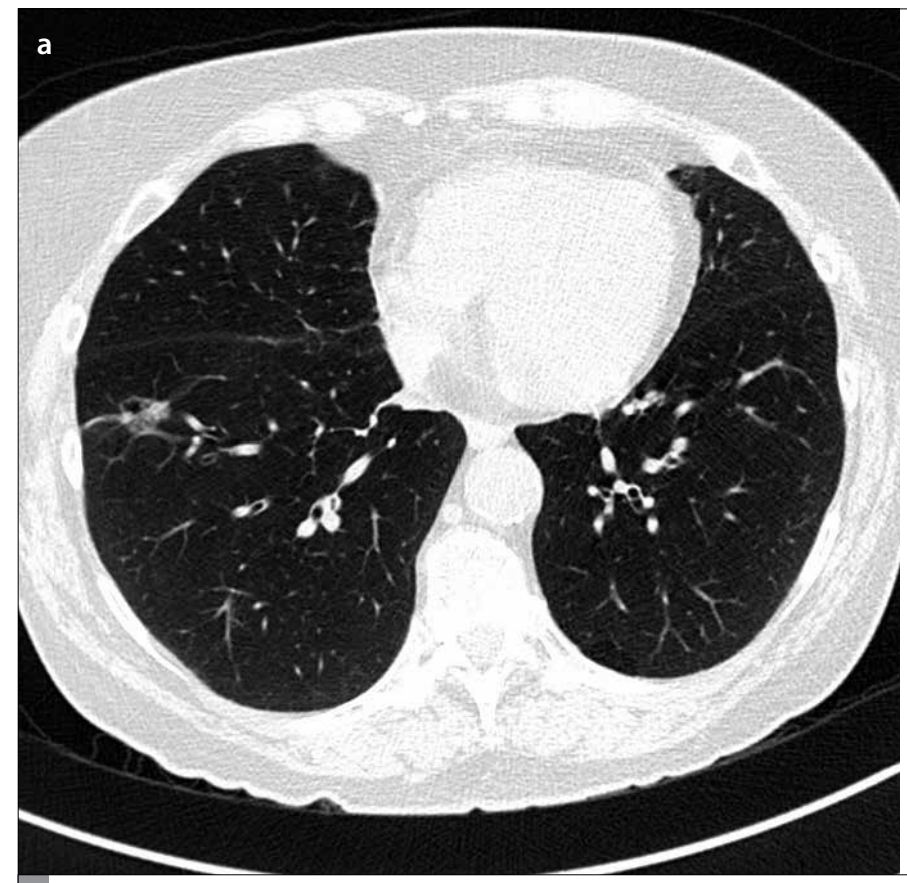

\section{Screening for Lung Cancer in USA}

The eligibility criteria for enrolling in the NLST included age 55-74 years, current or former smokers of at least 30 pack-years, and former smokers could not have quit more than 15 years before entry. It is estimated that only $26.7 \%$ of lung cancer patients seen in the USA in any 1 year would have met the criteria for enrollment into the trial (9). Approximately 8.6 million Americans met the NLST criteria for

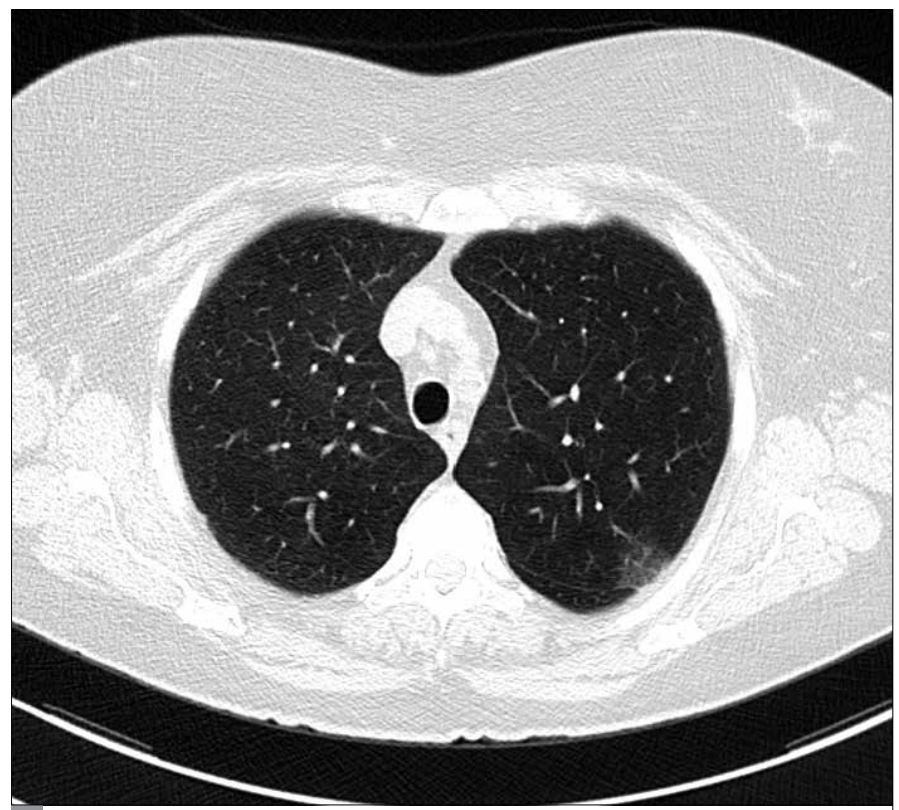

Figure 1. CT scan from a 73-year-old female former smoker. The $\mathrm{CT}$ shows a ground glass density lesion that is not visible on chest radiograph. This lesion was resected 15 months after this CT scan and proved to be adenocarcinoma in situ (Stage 0 ).

Figure 2. a, b. This low-dose screening CT scan was read out by the radiologist as showing a 1.6 -cm focal course linear density and irregular consolidation in the anterior right lower lobe (a). The patient was followed with CT scans at 4 months and 10 months, and the lesion was stable. A following CT scan 14 months after the initial CT scan demonstrated enlargement and measured $1.9 \mathrm{~cm}$. At resection, it proved to be a low-grade adenocarcinoma, Stage IA (b). 
screening in 2010. If LDCT screening were to be fully adopted, then approximately 12,000 lung cancer deaths would be averted each year (10). The USPSTF modeling study estimated that 18,000 lung cancer deaths per year might be avoided in the US with LDCT screening (8).

The US Preventive Services Task Force (USPSTF) is an independent panel of non-federal experts in prevention and evidence-based medicine, and it conducts scientific reviews of a broad range of clinical preventive health services, including screening, and develops recommendations for primary care clinicians and health systems. The USPSTF issued a recommendation statement based on the review of screening for lung cancer with LDCT. The USPSTF recommends annual screening for lung cancer with LDCT in adults 55 to 80 years who have a 30 pack-year smoking history and are current smokers or have quit within the past 15 years (11). Individuals should not have health problems that significantly limit life expectancy or are unwilling to have curative lung surgery. The level of this recommendation was Grade B. A Grade B recommendation means that the test is recommended and there is high certainty that the net benefit is moderate or there is moderate certainty that the net benefit is moderate to substantial. Based on the 2010 Affordable Care Act (Obamacare), those services that receive a USPSTF recommendation of A or B must be provided free of charge by the insurance company to their participant. Medicare (insurance for individuals $\geq 65$ years) is a government insurance, and they may pay for screening with LDCT, but they are not absolutely required to do so based on the USPSTF recommendation. At this time (March 2014), the Centers for Medicare and Medicaid are considering the option of paying for screening with LDCT for lung cancer. A decision is expected later in 2014.

\section{Cost Effectiveness}

There have been wide variations in the estimates of cost effectiveness of screening with LDCT. These are based on various models and estimates. Investigators from the Early Lung Cancer Action Project estimated that a single baseline CT scan had a cost effectiveness of $\$ 2500$ per year of life saved (12). McMahon and colleagues estimated that annual screening of high-risk individuals with a minimum of 20 pack-years of smoking costs between $\$ 126,000$ and $\$ 169,000$ per quality-adjusted life-year (QALY) (13). For former smokers, Mahadeva and associates estimated a cost of $\$ 2,322,700$ per QALY (14). In current smokers, this decreased to $\$ 116,300$ per QALY.

At the 2013 World Congress on Lung Cancer in Sydney, Australia, Dr. Christine Berg reported on the preliminary analysis of the cost-effectiveness of LDCT screening in the NLST. Compared to no screening, LDCT screening costs $\$ 1441$ per person and $\$ 67,000$ per QALY (15). A peer-reviewed publication of these results is anticipated in 2014. This cost per QALY is under the $\$ 100,000$ per QALY level in the US, indicating good value for the money (16).

The USPSTF analysis of cost-effectiveness did not take into consideration the rate of smoking cessation in the study. Smoking cessation was evaluated in the Dutch-Belgian randomized trial (NELSON) (17). Almost $17 \%$ of the trial participants quit smoking. However, the 1 -year continued abstinence rates were $12.6 \%$ in the screened arm and $14.6 \%$ in the control arm. Thus, it appears that participants in a screening trial, regardless of which arm of the study they are in, are highly motivated to quit. In the single-arm Pan-Canadian screening trial, all participants were screened with LDCT. The smoking cessa- tion rate at 2 year was $20 \%$ (personal communication with PI: Dr. Stephen Lam). Accordingly, if a smoking cessation rate of $10-20 \%$ were to be included in the cost analysis of LDCT screening, it would lower the cost for QALY. Using modeling data, investigators have estimated that offering smoking cessation with annual LDCT screening would improve the cost-effectiveness of screening by $20-45 \%$ (18).

\section{Screening High-Risk Individuals}

Investigators evaluated the efficacy of LDCT screening in the NLST based on the 5-year risk of death from lung cancer death (19). The risk was divided into five quintiles of risk. They were able to show that $88 \%$ of the prevented lung cancer deaths occurred in the top three quintiles of risk (top 60\%). Likewise, the number of participants needed to be screened to prevent one lung cancer death decreased to 208 versus 302 for all five quintiles. The number of false-positive LDCT scans to prevent one lung cancer death also decreased significantly. Similar trends in trends in lung cancer mortality ratios and mortality differences were observed with risk quintiles based on either risk of lung cancer death or the predicted risk of lung cancer $(19,20)$.

Tammemagi and colleagues developed and validated a lung cancer risk prediction model based on data from North Americans enrolled in the Prostate, Lung, Colorectal, and Ovarian (PLCO) Screening Trial (JNCl Study). They modified the risk prediction model of PLCO to make it applicable to the NLST participants (20). The use of the new PLCO risk model was more sensitive than the NLST eligibility criteria for lung cancer detection. The PLCO risk model had improved sensitivity ( $83 \%$ versus $71 \%$ ) without loss of specificity $(62.9 \%$ versus $62.7 \%$ ). Overall, the PLCO risk model identified 81 more of the 678 lung cancers. The lung cancer risk prediction calculator is available online at http://www.brocku.ca/lung-cancer-risk-calculator.

\section{Screening Schedules}

The NLST performed LDCT once a year for three scans and then followed participants for an additional 6.5 years without screening. The yearly screening interval was an empirical decision based on the usual screening interval for other screening tests (e.g., mammography). Limiting the screening to 3 years was based on costs and financial limitations of funding the study (3). In comparison, the NELSON trial performed baseline screening with LDCT and then again at 1 year and 3 years. They skipped the 2-year screening time point. The mortality results of the NELSON trial have not yet been reported (21). Accordingly, no conclusion can be made on the efficacy of the NELSON trial screening interval. Recently, the Cancer Care Ontario's Program on Evidenced-Based Care has recommended that persons at high risk for lung cancer should be screened for 3 consecutive years and then once every 2 years after each negative scan (22).

The comparative modeling study for the USPSTF evaluated results of screening every 3 years, every 2 years, and yearly. The eight most efficient screening programs all involved yearly screening with LDCT scans (8).

\section{CONCLUSION}

It is estimated that a significant proportion of lung cancers in the world would be prevented if existing programs for tobacco control were to be implemented. These include raising the price of cigarettes 
and other tobacco products (e.g., hookahs), banning smoking in public, restricting advertising of tobacco, and treating tobacco dependence (23). Since the publication of the first United States surgeon general report on smoking and death in 1964, it is estimated that tobacco control in the USA has been associated with avoidance of 8 million premature deaths and an extended mean life span of 19-20 years for each beneficiary (24).

Smoking cessation should be part of any lung cancer screening program with LDCT. Screening is an opportunity to educate individuals as to the risks of smoking and expose them to methods of smoking cessation and programs to assist in their efforts to quit smoking, such as the US Centers for Disease Control website, http://www.cdc.gov/ tobacco/campaign/tips/.

Screening with LDCT in high-risk individuals is becoming the standard of care in the United States and, along with smoking cessation, offers the best opportunity for decreasing a substantial number of lung cancer deaths.

\section{Ethics Committee Approval: N/A.}

Informed Consent: N/A.

Peer-review: Externally peer-reviewed.

Conflict of Interest: No conflict of interest was declared by the author.

Financial Disclosure: The author's institution received a research grant from Oncimmune for biomarker study of early detection.

\section{REFERENCES}

1. IARC WHO. Globocan 2012. http://globocan.iarc.fr.

2. Siegel R, Ma J, Zou Z, Jemal A. Cancer statistics, 2014. CA Cancer J Clin 2014; 64: 9-29. [CrossRef]

3. National Lung Screening Trial Research T, Aberle DR, Adams AM, Berg CD, Black WC, Clapp JD, et al. Reduced lung-cancer mortality with low-dose computed tomographic screening. N Eng J Med 2011; 365: 395-409. [CrossRef]

4. National Lung Screening Trial Research T, Church TR, Black WC, Aberle $\mathrm{DR}$, Berg CD, Clingan KL, et al. Results of initial low-dose computed tomographic screening for lung cancer. N Eng J Med 2013; 368: 1980-91. [CrossRef]

5. Aberle DR, DeMello S, Berg CD, Black WC, Brewer B, Church TR, et al. Results of the two incidence screenings in the national lung screening trial. N Eng J Med 2013; 369: 920-31. [CrossRef]

6. Veronesi G, Maisonneuve P, Bellomi M, Rampinelli C, Durli I, Bertolotti $\mathrm{R}$, et al. Estimating overdiagnosis in low-dose computed tomography screening for lung cancer: a cohort study. Ann Itern Med 2012; 157: 776-84. [CrossRef]

7. Patz EF, Jr., Pinsky P, Gatsonis C, Sicks JD, Kramer BS, Tammemagi MC, et al. Overdiagnosis in low-dose computed tomography screening for lung cancer. JAMA Intern Med 2014; 174: 269-74. [CrossRef]

8. de Koning HJ, Meza R, Plevritis SK, ten Haaf K, Munshi VN, Jeon J, et al. Benefits and harms of computed tomography lung cancer screening strategies: A comparative modeling study for the U.S. Preventive services task force. Ann Intern Med 2014; 160: 311-20. [CrossRef]

9. Pinsky PF, Berg CD. Applying the national lung screening trial eligibility criteria to the us population: What percent of the population and of incident lung cancers would be covered? J Med Screen 2012; 19: 154-56. [CrossRef]

10. Ma J, Ward EM, Smith R, Jemal A. Annual number of lung cancer deaths potentially avertable by screening in the United States. Cancer 2013; 119: 1381-5. [CrossRef]

11. Moyer VA. Screening for lung cancer: U.S. Preventive services task force recommendation statement. Annals of internal medicine 2014; 160: 3308. [CrossRef]

12. Wisnivesky JP, Mushlin Al, Sicherman N, Henschke C. The cost-effectiveness of low-dose ct screening for lung cancer: Preliminary results of baseline screening. Chest 2003; 124: 614-21. [CrossRef]

13. McMahon PM, Kong CY, Bouzan C, Weinstein MC, Cipriano LE, Tramontano AC, et al. Cost-effectiveness of computed tomography screening for lung cancer in the United States. J Thorac Oncol 2011; 6: 1841-8. [CrossRef]

14. Mahadevia PJ, Fleisher LA, Frick KD, Eng J, Goodman SN, Powe NR. Lung cancer screening with helical computed tomography in older adult smokers: a decision and cost-effectiveness analysis. JAMA 2003; 289: 313-22. [CrossRef]

15. Berg C. Cost effectiveness of ct screening. Journal of thoracic oncology: official publication of the International Association for the Study of Lung Cancer 2013; 8: 96.

16. Weinstein MC, Skinner JA. Comparative effectiveness and health care spending - implications for reform. N England J Med 2010; 362: 460-5. [CrossRef]

17. van der Aalst $C M$, van den Bergh KA, Willemsen $M C$, de Koning $H J$, van Klaveren RJ. Lung cancer screening and smoking abstinence: 2 year follow-up data from the dutch-belgian randomised controlled lung cancer screening trial. Thorax 2010; 65: 600-5. [CrossRef]

18. Villanti AC, Jiang Y, Abrams DB, Pyenson BS. A cost-utility analysis of lung cancer screening and the additional benefits of incorporating smoking cessation interventions. PloS one 2013; 8: e71379. [CrossRef]

19. Kovalchik SA, Tammemagi M, Berg CD, Caporaso NE, Riley TL, Korch M, et al. Targeting of low-dose CT screening according to the risk of lung-cancer death. N Eng J Med 2013; 369: 245-54. [CrossRef]

20. Tammemagi MC, Katki HA, Hocking WG, Church TR, Caporaso N, Kvale PA, et al. Selection criteria for lung-cancer screening. N Eng J Med 2013; 368: 728-36. [CrossRef]

21. van lersel CA, de Koning HJ, Draisma G, Mali WP, Scholten ET, Nackaerts $\mathrm{K}$, et al. Risk-based selection from the general population in a screening trial: Selection criteria, recruitment and power for the dutch-belgian randomised lung cancer multi-slice ct screening trial (nelson). Int J Cancer 2007; 120: 868-74. [CrossRef]

22. Roberts H, Walker-Dilks C, Sivjee K, Ung Y, Yasufuku K, Hey A, et al. Screening high-risk populations for lung cancer: Guideline recommendations. J Thorac Oncol 2013; 8: 1232-7. [CrossRef]

23. CDC. Best practices for comprehensive tobacco control programs. Available at http://wwwcdcgov/tobacco/stateand community/best_practices/indexhtm 2007; US Department of Health and Human Services.

24. Holford TR, Meza R, Warner KE, Meernik C, Jeon J, Moolgavkar SH, et al. Tobacco control and the reduction in smoking-related premature deaths in the united states, 1964-2012. JAMA 2014; 311: 164-71. [CrossRef] 